\title{
University Industry (U-I) Relationship: Evidence from an Egyptian University
}

\author{
Mansour S. M. Lotayif ${ }^{1}$ \\ ${ }^{1}$ Business Administration Department, Business College, Beni-Swef University, Egypt \\ Correspondence: Mansour S. M. Lotayif, Business Administration Department, Business College, Beni-Swef \\ University, Egypt. E-mail: Mansourlo@yahoo.com; Mansour.lotayif@asu.edu.bh
}

Received: January 21, 2015

Accepted: February 9, $2015 \quad$ Online Published: March 27, 2015

doi:10.5539/ijbm.v10n4p113

URL: http://dx.doi.org/10.5539/ijbm.v10n4p113

\begin{abstract}
The current study aims at identifying the causality relationships amongst (U-I) relationship's variables i.e. demographics, communication, trust, satisfaction, functional conflict, afflictive commitment, expectation of continuity, willingness to invest, and collaboration. The experiences of 216 Egyptian internship's companies were utilized to achieve these objectives. Throughout multivariate analytical technique (e.g. multiple regression), significant causality relationships have been supported these U-I relationships. However, only two significant relationships between demographics and both satisfaction, and commitment were found.
\end{abstract}

Keywords: relationship marketing, university-industry relationship (U-I)

\section{Introduction}

Nowadays, universities' roles expanded beyond research and education to other social and industrial roles. Abramo et al. (2011); Crespo and Dridi (2007); Gunasekara (2006); Siegel et al. (2003); Ballart and Subirats (1997) have discussed these roles such as the university's impact on local development, knowledge transfer, the contribution to innovation, and relationships with governments. In developing countries like Egypt, universities have a crucial roles in the sustainable development. Consequently U-I collaboration is vital in this perspective. Therefore, the current study is an endeavor in exploring the causality relationships in university-industry relationships (U-I).

\section{Literature Review}

University industry (U-I) collaboration is vital to both parties, it clarifies and shed light on what society needs from universities and in the same time gives universities a viable avenue to amend their curriculums for that mission. Marta et al. (2012) have addressed this topic (i.e. U-I collaboration) in higher education context (the experience of 322 Spanish companies taken from 1424 companies collaborated with Valencia university were utilized) by analyzing the role of communication as the basis of the relationship through its impact on trust, satisfaction, functional conflict, commitment and collaboration between firms and universities. In this perspective, only companies that have been participating in undergraduate internship's programme, in the area of social science, during the last three consecutive years been included. In their study, they found communication proved to be a significant antecedent of relational variables such as trust, satisfaction, and functional conflict. Also, the positive contribution of trust on commitment was not confirmed, but commitment was strongly influenced by satisfaction. Satisfaction also had a significant positive effect on trust but the hypothesized positive contribution of trust on collaboration was not supported. Finally the direct determinants of collaboration that appear significant are functional conflict and commitment. The current study builds on Marta's study by adopting a broad and comprehensive approach in investigating the causality relationships amongst communication, trust, satisfaction, functional conflict, affective commitment, expectation of continuity, willingness to invest, and collaboration. Consequently, it worth explaining each one of them in higher education context.

First, communication is defined as the formal and informal sharing of meaningful and timely information between firms (Anderson \& Narus, 1990, p. 44), and the glue that holds together partners in organizational relationships (Mohr \& Nevin, 1990). It uses in aligning objectives, resolving disputes, and creating opportunities (Morgan \& Hunt, 1994). Palmatier et al. (2007); Morgan and Hunt (1994); Anderson and Narus (1990) have 
considered communication a precursor of trust. In U-I context, there is a strong significant impact of communication on commitment, trust, and relationship satisfaction (Palmatier et al., 2006) and communication is an antecedent of other relationship characteristics such as trust, commitment and conflict (Plewa et al., 2005). Also, there is a positive link between communication and satisfaction (Mora et al., 2004). Moreover, there is an indirect link between communication and functional conflict (Morgan \& Hunt, 1994).

Second, trust is broadly defined as the firm's belief that another company will perform actions that will result in positive outcomes for the firm without unexpected actions that would result in negative outcomes for the firm (Anderson \& Narus, 1990). Therefore, trust is an aggregate evaluation that occurs at a higher level than satisfaction and reflects the level of satisfaction in the customer-provider relationship (Garbarino \& Johnson, 1999; Ravald \& Gronroos, 1996). Morgan and Hunt, 1994 added that trust exists when one party has confidence in an exchange partner's reliability and integrity. In higher education context and from student perspective, trust could be defined as "the degree to which a student is willing to rely on or have faith and confidence in the organization to take appropriate steps that benefit him and help him achieve his learning and career objectives" (Ghosh et al., 2001, p. 325). From industry perspective, trust existed when universities consistently graduate the appropriate and qualified candidates who match labor market's requirements. Also, trust existed when universities participate massively in solving industries' problems by pleading viable solutions in this perspective. In U-I context, significant relation between communication and trust has been approved (Mora et al., 2004).

Third, functional conflict is the dispute between two organizations as a result of failure in business communication around mutual interests. Failure in business communication leads to both dissatisfaction and conflict that conflict shaped in tension, stress, anger, or frustration (Skarmeas, 2006). Functional conflict in U-I relationship is the evaluative appraisal of the results of recent efforts to resolve disagreements (Anderson \& Narus, 1990). Commitment is a key factor of relational outcomes, including cooperation (Palmatier et al., 2007).

Forth, satisfaction is defined as the state achieved when service or product features respond to customer needs and when the company meets or exceeds customers' expectations over the life time of a product or service (Juran, 1988). Kotler and Clarke (1987) added that satisfaction is multilevel terminology which is gradually reached after undergoing various stages of fulfilled expectations after a service is performed in a certain way or product is sold and consumed. Therefore, satisfaction is the positive comparison between "expectations" and "perceptions" conducted by every single customer (Arif et al., 2013, Lotayif, 2009). Arambewela and Hall (2009), Oliver (1980) and Anderson (1973) added that satisfaction is related to the size and direction of disconfirmation, which is defined as the difference between an individual's pre-purchase (pre-choice) expectations (or some other comparative standard) and the post-purchase (post-choice) performance of the product or service as perceived by the. If expectations are met or exceeded, the customer is satisfied and dissatisfaction results when the perceived performance falls below expectation. The same logic exists in U-I relationship.

Fifth, commitment is defined as a stabilizing force that binds and obligates anybody to certain target-relevant types of behavior, therefore it is a specific mindset that compels an individual toward a course of action (Meyer \& Herscovitch, 2001, p. 303). Commitment leads to specific course of actions (Lam \& Yan, 2014). These set of actions reflected on the desire to build constructive relations between universities and industries.

Sixth, collaboration and team are commonly used terminologies in the literature (Croker et al., 2009), and, there is not yet a clear definition nor a process measurement of collaboration in the area of U-I (Kohengkul et al., 2009 , p. 2). Generally, collaboration could be defined as the cooperation between two or more organizations or individuals in a permanent or temporary mission aims at creating a useful and valuable innovation to achieve sets of common goals. In U-I context, that collaboration might take different forms such as informal technology consultations, collaborative R\&D performed on a contractual basis (Motohashi, 2005), training centers, and internships programs. Of course, the level of collaboration is function in the level of mutual satisfaction i.e. the higher the satisfaction level, the more tendency for collaboration (Kohengkul et al., 2009); and Ulaga and Eggert, 2006). For the remaining two variables i.e. expectation of continuity, and willingness to invest have been adopted from Marta's study (2012) for the same discussion and logic mentioned there. In other words, expectation of continuity means doing business with the university in the long run, and the renewal of the contractual relationship will be automatically simply because there are mutual benefits between the two parties. Finally, willingness to invest means the desire to enhance the collaboration level in the foreseen future and building a long lasting relationship. In figure 1, the causal relationships amongst these variables are suggested and will be tested. 


\section{Research Objectives}

The current study aims at exploring the following causality relationships in Egyptian context:

1) Exploring the relationships between demographics (i.e. type of business, ownership, experience, size, and frequency of collaboration) and relationship's variables (i.e. communication, trust, satisfaction, functional conflict, afflictive commitment, expectation of continuity, willingness to invest, and collaboration); and

2) Exploring the relationships amongst (U-I) relationship's variables (i.e. communication, trust, satisfaction, functional conflict, afflictive commitment, expectation of continuity, willingness to invest, and collaboration).

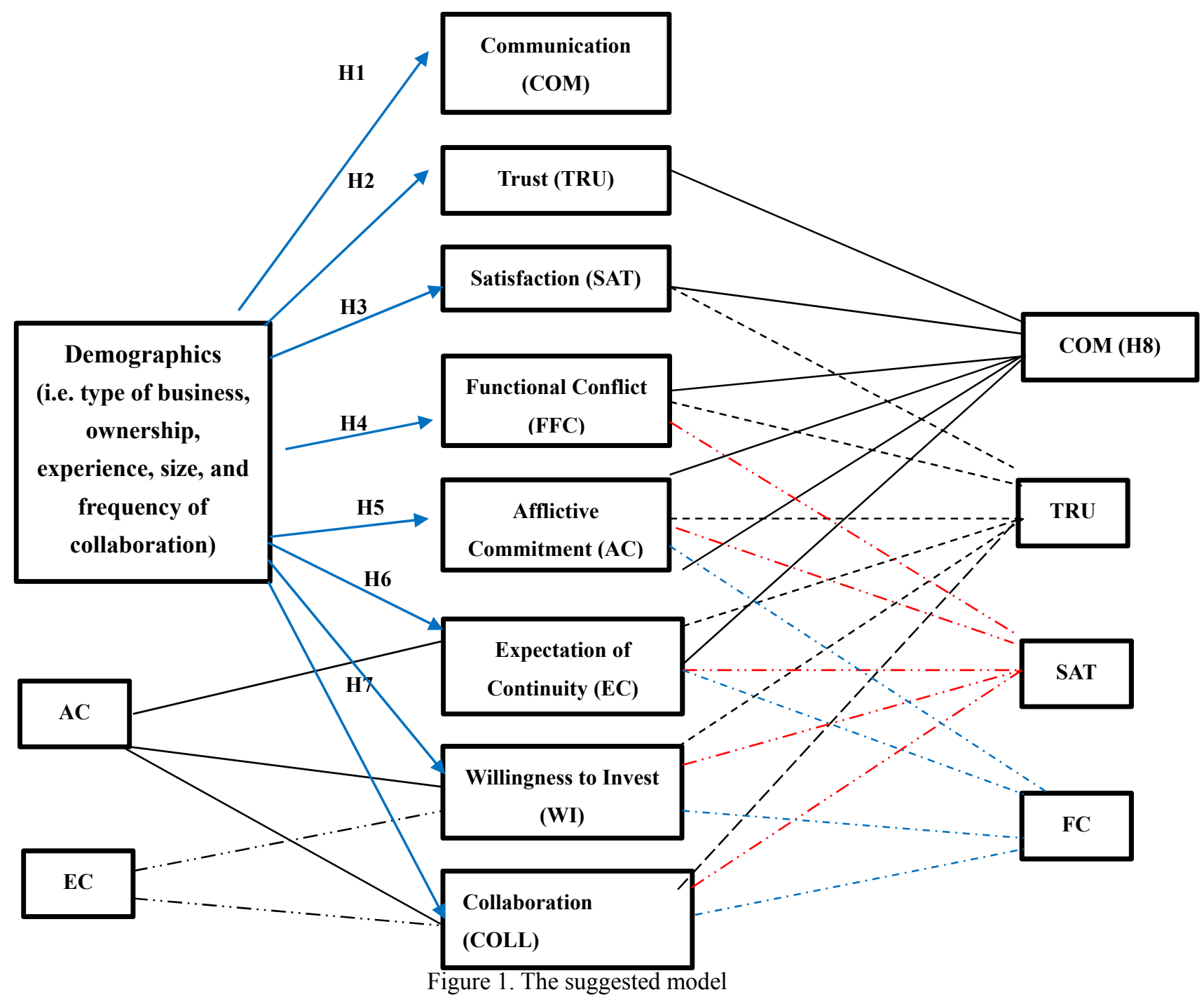

\section{Research Hypotheses}

The following hypotheses are proposed to achieve the study's objectives:

H1: There is a significant causality relationship between communication and demographics (i.e. type of business, ownership, experience, size, and frequency of collaboration);

H2: There is a significant causality relationship between trust and demographics (i.e. type of business, ownership, experience, size, and frequency of collaboration);

H3: There is a significant causality relationship between satisfaction and demographics (i.e. type of business, ownership, experience, size, and frequency of collaboration);

H4: There is a significant causality relationship between functional conflict and demographics (i.e. type of 
business, ownership, experience, size, and frequency of collaboration);

H5: There is a significant causality relationship between afflictive commitment and demographics (i.e. type of business, ownership, experience, size, and frequency of collaboration);

H6: There is a significant causality relationship between expectation of continuity and demographics (i.e. type of business, ownership, experience, size, and frequency of collaboration);

H7: There is a significant causality relationship between willingness to invest and demographics (i.e. type of business, ownership, experience, size, and frequency of collaboration);

H8: There is a significant causality relationship between communication and (collaboration, trust, expectation of continuity, functional conflict, willingness to invest, affective commitment, and satisfaction);

H9: There is a significant causality relationship between trust, and (collaboration, satisfaction, expectation of continuity, functional conflict, willingness to invest, and affective commitment);

H10: There is a significant causality relationship between satisfaction, and (collaboration, expectation of continuity, functional conflict, willingness to invest, and affective commitment);

H11: There is a significant causality relationship between functional conflict, and (collaboration, expectation of continuity, willingness to invest, and affective commitment);

H12: There is a significant causality relationship between affective commitment, and (collaboration, expectation of continuity, and willingness to invest); and

H13: There is a significant causality relationship between expectation of continuity, and (collaboration, and willingness to invest).

\section{Study Methodology}

This part includes the followings: (1) determining the deployed research paradigm (2) the population from which a representative sample was selected; (3) data collection method; (4) statistical packages and statistical techniques deployed in the current study. Firstly, for research paradigm, a positivistic approach through using a structured questionnaire was adopted. Secondly, a convenience sample of 216 internship course' companies at Cairo University-Georgia program in Egypt- has been utilized in the current study. In this perspective, only companies that have been participating in undergraduate internship's programme, in the area of social science, during the last three consecutive years were included. This Georgia program started at 2006 and has four different specializations e.g. finance, marketing, management, and accounting. Thirdly, an eight concept structured questionnaire with eleven-point Likert scale was deployed and filled by general managers of internship's firms. These eight concepts are communication (COM1, COM2, COM3, COM4, and averaged by COM5), trust (TRU1, TRU2, TRU3, and averaged by TRU4), satisfaction (SAT1, SAT2, SAT3, and averaged by SAT4), functional conflict (FC1, FC2, FC3, and averaged by FC4), affective commitment (AC1, AC2, AC3, and averaged by AC4), expectation of continuity (EC1, EC2, EC3, and averaged by EC4), willingness (WI1, WI2, WI3, and averaged by WI4), and collaboration (COLLAB1). The questionnaire coupled with the covering letter explaining the research objectives were handled to every response base (i.e. managers of internship firms cooperated with Georgia program in Cairo University). The response rate was 72 percent, as the completed and returned questionnaires were 216 out of 300 questionnaires. Finally, SPSS release twenty one was used as a data analysis package. Multiple regression was deployed as analytical statistical technique.

\section{The Study Findings}

In this part sample normality, regressors multi-collinearity, scale validity, reliability, hypotheses testing, conclusion and recommendations will be discussed.

\subsection{Normality, Multi-Collinearity, Validity, and Reliability}

Data distribution's shape is considered normal when the sample size is bigger than 30 cases (Ortuzar \& Willumsen, 1994). Consequently, normality dimension is assumed, as sample's size is 216 cases in the current study. Statistically, instrument and concepts are considered reliable when the value of Cronbach alpha coefficient is bigger than 60 percent (Foster, 2001, p. 228; Teo \& King, 1996; Malhotra, 1993, p. 308). 
Table 1. Reliability of instrument and concepts

\begin{tabular}{lllll}
\hline Instrument and Concepts & $\mathrm{N}$ & $\mathrm{N}$ of Items & Alpha \\
\hline - & Instrument & 216 & 30 & .96 .9 \\
1. & Communication & 216 & 5 & .92 .8 \\
2. & Trust & 216 & 4 & .93 .0 \\
3. & Satisfaction & 216 & 4 & .92 .7 \\
4. & Functional conflict & 216 & 4 & .96 .5 \\
5. & Commitment & 216 & 4 & .95 .8 \\
6. & Expectation of continuity & 216 & 4 & .85 .5 \\
7. & Willingness to invest & 216 & 4 & .93 .1 \\
\hline
\end{tabular}

Note. Collaboration variable is measured via only one question (item) therefore it is included in instrument analysis not concept analysis, as it is not a concept.

As shown in Table 1, Cronbach alpha coefficients are 0.96.9, 0.92.8, 0.93.0, 0.92.7, 0.96.5, 0.95.8, 0.85.5 and 0.93 .1 percent for the whole instrument and for every single instrument's concept i.e. communication, trust, satisfaction, functional conflict, commitment, expectation o continuity, and willingness to invest respectively. Therefore, reliability dimension in the current study is supported. Multi-collinearity amongst study's regressors is supported, as all correlations' coefficients show values less than unity, as shown in Tables (2, and 3).

Table 2. Multi-collinearity of regressors

\begin{tabular}{|c|c|c|c|c|c|}
\hline \multirow[t]{2}{*}{ Independent Variables } & \multicolumn{5}{|c|}{ Independent Variables } \\
\hline & Business & Ownership & Experience & Size & Frequency \\
\hline Business & $\ldots$. & & & & \\
\hline Ownership & 649 & $\ldots$. & & & \\
\hline Experience & 529 & 608 & $\ldots$. & & \\
\hline Size & 022 & 160 & 282 & $\ldots$. & \\
\hline Frequency & 346 & 370 & 451 & 034 & $\ldots$. \\
\hline
\end{tabular}

Note. Number of matrix's cells $=\mathrm{n}(\mathrm{n}-1) / 2$, where $\mathrm{n}=$ Number of independent variables $\{5(5-1) / 2=\mathbf{1 0}\}$ Variables.

For instrument's validity, grouped discussions with colleagues and fellow academics suggested some minor paraphrasing and typo amendments. Literally, validity refers to the extent to which a test measures the concept(s) that it intends or claims to measure (Lotayif, 2014, Bryman \& Cramer, 1999; Rust \& Golomok, 1999; Kline, 1997; Nunnally, 1978). Unlike reliability, there is no single figure which indicates test validity (Kline, 1997). Stodnick et al. (2008); Saravanan et al. (2007); El-Ragal (2001); Keil et al. (2000); Ravichandran and Rai (2000); Bryman and Cramer (1999); Rust and Golomok (1999); Chan et al. (1998); Kline (1997); Wonnacott and Wonnacott (1990); Ghiselli et al. (1981); and Nunnally (1978) distinguish between types of validity. These types are face, contents, predictive (criterion-related validity), construct, concurrent, convergent, divergent, and discriminant validities.

Face validity refers to the appearance of the instrument. Therefore, it includes everything related to collect the required data for the intended purposes, from questions design and order, to number of questions and so on. Face validity is measured by judgmental methods e.g. careful definition of the topic, items to be scaled, scale to be used and so on (El-Ragal, 2001). Content validity refers to the extent to which the instrument provides adequate coverage of the topic being researched (Rust \& Golomok, 1999). To ensure these two kinds of validity, the questionnaire was piloted on fellow academics for consultation as well as industry participants, and amended in the light of comments and recommendations made. Construct validity refers to identify the underlying construct(s) being measured and determine how well the test represents them. It is usually measured by factor analysis (Bryman \& Cramer, 1999). As the questionnaire is made of ten main and well know parts i.e. constructs, construct validity is assumed, as these constructs been used in the literature (e.g., Duncan \& Jana, 2012; Bowden, 2011; Plewa \& Quester, 2008; Kumar et al., 1995).

Predictive validity/Criterion-related validity refers to ability of a test to predict some relevant outcome (Saravanan et al., 2007). To assess this kind of validity, criterion to be compared with should be available. However, it is difficult to set up a good criterion to upon which to base predictions. Therefore, predictive validity 
is of little use (Bryman \& Cramer, 1999). Concurrent validity refers to correlating a test with another test of the same variable (Rust \& Golomok, 1999). Satisfactory concurrent validity requires a correlation of at least 0.7 between the two tests (El-Ragal, 2001). Scales differences impose restrictions on conducting this kind of validity. Discriminant validity refers to the strength of correspondence between a measure and other measures which are supposed to represent other concepts (Bryman \& Cramer, 1999). Ghiselli et al. (1981) stated that correlation coefficient greater than 0.80 represent extreme cases. Finally, convergent validity refers to the attempt to demonstrate that each measure harmonizes with another measure (El-Ragal, 2001; Bryman \& Cramer, 1999; Chan et al., 1998). Using observations in addition to the questionnaire could guarantee this kind of validity, a procedure not followed here (El-Ragal, 2001).

\subsection{Hypotheses Testing}

As shown in Table 3 and based on Multiple Regression (MR) results, there is significant causality relationship between demographics (i.e. type of business, ownership, experience, size, and frequency of collaboration) and satisfaction, as $\mathrm{p}=0.011<0.05$. Also, there is significant causality relationships between demographics and commitment, as $\mathrm{p}=0.021<0.05$. Consequently, the alternative hypotheses $\mathrm{H}_{3}$ and $\mathrm{H}_{5}$ are supported. However, there are no significant causality relationships between demographics and communication, trust, functional conflict, expectation of continuity, willingness to invest, as $\mathrm{p}<0.05$. Consequently, the alternative hypotheses $\mathrm{H} 1, \mathrm{H} 2, \mathrm{H} 4, \mathrm{H} 6$, and $\mathrm{H} 7$ are not supported. The most remarkable things are:

- Data entry order process did not affect on its analysis, as Durbin-Watson test reported values $>1.4$ for all dependent variables, as shown in Table 3.

- The explanation powers of these two models (the supported hypotheses) represented by "R square" and "adjusted R" are 26, and 24 percent and 6.7 and 6.1 percent respectively are low. That means the magnitude of these demographics on study variables, as cause and effect relationship, are weak. Consequently, other variables will be explored rather than the demographics in the current study, as shown in Table 3.

Table 3. Multiple regressions between demographics (IVs) and communication, trust, satisfaction, functional conflict, commitment, expectation of continuity, and willingness to invest (DVs)

\begin{tabular}{|c|c|c|c|c|c|c|}
\hline (Regressors or IVs) & $\mathbf{F}$ & P-value & $\mathbf{R}$ & $\begin{array}{l}\mathbf{R} \\
\text { Square } \\
\end{array}$ & $\begin{array}{l}\text { Adjusted R } \\
\text { Square }\end{array}$ & $\begin{array}{l}\text { Durbin-W } \\
\text { atson }\end{array}$ \\
\hline Communication & 2.106 & 0.066 & 0.219 & 0.048 & 0.025 & 1.464 \\
\hline Trust & 1.309 & 0.261 & 0.174 & 0.030 & 0.007 & 1.507 \\
\hline Satisfaction & 3.037 & $0.011 * * *$ & 0.260 & 0.067 & 0.045 & 1.190 \\
\hline Functional Conflict & 1.126 & 0.348 & 0.162 & 0.026 & 0.003 & 1.484 \\
\hline Commitment & 2.717 & $0.021 * * *$ & 0.246 & 0.061 & 0.038 & 1.484 \\
\hline Expectation of Continuity & 0.852 & 0.514 & 0.141 & 0.020 & 0.003 & 1.636 \\
\hline Willingness to Invest & 1.793 & 0.116 & 0.202 & 0.041 & 0.018 & 1.521 \\
\hline
\end{tabular}

$>\left({ }^{* *}\right)$ There is a significant relationship between at least one of the independent variables and model dependent variable as $p<0.05$.

$>\mathbf{R}$ Square $=$ indicates the effect the independent variables have on the dependent one in the sample.

$>$ Adjusted R Square $=$ reflects the model goodness of fit for the population.

$>$ Durbin-Watson is a test to indicate the effect of data entry order in the analysis, therefore if it is $>1.4$ it means the order has no effect on the analysis and if it is less, it means the order has affected the analysis (Stat graphics 2000).

As shown in Table 4 and based on Multiple Regression (MR) results, there is a significant causality relationship between communication and (collaboration, trust, expectation of continuity (EC), functional conflict (FC), willingness to invest (WI), affective commitment (AC), and satisfaction (SAT), as $p<0.05$. Therefore $\boldsymbol{H} \boldsymbol{8}$ is supported. Also, there is a significant causality relationships between trust, and (collaboration, satisfaction, expectation of continuity, functional conflict, willingness to invest, and affective commitment), as $p<0.05$. Therefore $\boldsymbol{H 9}$ is supported. Moreover, there is a significant causality relationship between satisfaction, and (collaboration, expectation of continuity, functional conflict, willingness to invest, and affective commitment), as $p<0.05$. Therefore $\boldsymbol{H 1 0}$ is supported. There is a significant causality relationship between functional conflict, and (collaboration, expectation of continuity, willingness to invest, and affective commitment), as $p<0.05$. 
Therefore $\boldsymbol{H} 1 \mathbf{1}$ is supported. There is a significant causality relationship between affective commitment, and collaboration, expectation of continuity, and willingness to invest), as $p<0.05$. Therefore $\boldsymbol{H 1 2}$ is supported. There is a significant causality relationship between expectation of continuity, and (collaboration, and willingness to invest), as $p<0.05$. Therefore $\boldsymbol{H 1 3}$ is supported. The most remarkable things are:

- Data entry order process did not affect on its analysis, as Durbin-Watson test reported values $>1.4$ for all dependent variables, as shown in Table 4.

- The explanation powers of these models represented by "R square" and "adjusted R" are 47.5, 62.6, $58.9,43.9,57$, and 37.4 percent and $45.7,61.5,58,42.9,56.4$, and 36.9 percent respectively. It is obvious that trust model components have the highest explanation power, as it represents 61.5 percent and expectation of continuity model's components have the least explanation power, as it represents 36.9 percent.

Table 4. Multiple regressions between study's variables

\begin{tabular}{|c|c|c|c|c|c|c|}
\hline & $\mathrm{F}$ & P-value & $\mathrm{R}$ & $\begin{array}{l}\mathrm{R} \\
\text { Square }\end{array}$ & $\begin{array}{l}\text { Adjusted R } \\
\text { Square }\end{array}$ & Durbin-Watson \\
\hline $\begin{array}{l}\text { Communication \{COLLAB, TRU4, EC4, FC4, WI4, AC4, } \\
\text { SAT4\} }\end{array}$ & 26.930 & $0.000 * * *$ & 0.689 & 0.475 & 0.457 & 1.635 \\
\hline Trust $\{$ COLLAB, SAT4, EC4, FC4, WI4, AC4 $\}$ & 58.474 & $0.000 * * *$ & 0.791 & 0.626 & 0.615 & 1.989 \\
\hline Satisfaction $\{$ COLLAB, FC4, EC4, WI4, AC4 $\}$ & 60.388 & $0.000 * * *$ & 0.767 & 0.589 & 0.580 & 1.591 \\
\hline Functional Conflict $\{$ COLLAB, EC4, WI4, AC4 $\}$ & 41.441 & $0.000 * * *$ & 0.663 & 0.439 & 0.429 & 1.871 \\
\hline Afflictive Commitment $\{$ COLLAB, EC4, WI 4$\}$ & 93.826 & $0.000 * * *$ & 0.755 & 0.570 & 0.564 & 1.997 \\
\hline Expectation of Continuity $\{$ COLLAB, WI 4$\}$ & 63.865 & $0.000 * * *$ & 0.612 & 0.374 & 0.369 & 1.981 \\
\hline
\end{tabular}

Notes.

$>\quad(* * *)$ There is a significant relationship between at least one of the independent variables and model dependent variable as $p<0.05$.

$>\quad \mathbf{R}$ Square $=$ indicates the effect the independent variables have on the dependent one in the sample.

$>$ Adjusted R Square $=$ reflects the model goodness of fit for the population.

$>$ Durbin-Watson is a test to indicate the effect of data entry order in the analysis, therefore if it is $>1.4$ it means the order has no effect on the analysis and if it is less, it means the order has affected the analysis (Stat graphics 2000).

The fact of the matter any model could exist if at least one variable reports significant relationship with the dependent variable. Here as shown in Table 5, all the dependent variables report significant relationships with their models' variables. For instance, communication reports positive significant relationship with trust (39.7), satisfaction (43.2), functional conflict (37.1), commitment (35.2), expectation of continuity (27.1), willingness to invest (29.8), and collaboration (26.2) percent. By the same logic, all other dependent variables (i.e. trust, satisfaction, functional conflict, affective commitment, and expectation of continuity) report signification relationships with their regressors, as shown in Table 5.

Table 5. Correlation coefficients

\begin{tabular}{|c|c|c|c|c|c|c|c|c|}
\hline Model Variables & COM5 & TRU4 & SAT4 & $\mathrm{FC} 4$ & $\mathrm{AC} 4$ & $\mathrm{EC} 4$ & WI4 & COLLAB \\
\hline Communication (COM5) & $\ldots \ldots .$. & & & & & & & \\
\hline Trust (TRU4) & $.397^{* *}$ & ....... & & & & & & \\
\hline Satisfaction (SAT4) & $.432^{* *}$ & $.554^{* *}$ & ........ & & & & & \\
\hline Functional Conflict (FC4) & $.371^{* *}$ & $.428^{* *}$ & $.526^{* *}$ & ........ & & & & \\
\hline Afflictive Commitment (AC4) & $.352^{* *}$ & $.443^{* *}$ & $.511^{* *}$ & $.431^{* *}$ & ........ & & & \\
\hline Expectation of Continuity (EC4) & $.271^{* *}$ & $.363^{* *}$ & $.456^{* *}$ & $.433^{* *}$ & $.557^{* *}$ & ........ & & \\
\hline Willingness to Invest (WI4) & $.298^{* *}$ & $.365^{* *}$ & $.400^{* *}$ & $.380^{* *}$ & $.449^{* *}$ & $.440^{* *}$ & ........ & \\
\hline Collaboration (COLLAB) & $.262^{* *}$ & $.288^{* *}$ & $.297^{* *}$ & $.335^{* *}$ & $.379^{* *}$ & $.313^{* *}$ & $.512^{* *}$ & ........ \\
\hline
\end{tabular}

$>$ Correlation more than 0.50 means strong significant relationship.

$>$ Correlation less than 0.50 means $\underline{\text { weak }}$ significant relationship.

$>$ Correlation equal0.50 means medium significant relationship. 


\subsection{Conclusion, Discussions, and Recommendations}

The current study is an endeavor to test the causality relationships of U-I relationship's variables in an Egyptian context. These variables are communication, trust, satisfaction, functional conflict, afflictive commitment, expectation of continuity, willingness to invest, and collaboration. Evidences from the Egyptian context supported the causality relationship between communication and the rest of other U-I variables. This represents a good inductive about the crucial and vital role that business communication has in building bridges of trust with businesses, in increasing businesses' satisfaction resulted from that constructive communication which inevitably has a positive effects of societies' sustainable development. Also, communication has positive effects on easing tensions and conflicts with businesses which increase the possibilities and willingness of these businesses to invest and continue these constructive and collaborated relationships with universities. It worth mentioning that these results goes hand in hand with the literature in this perspective as it confirms these significant relations discussed by Palmatier et al. (2006); Plewa et al. (2005), Mora et al. (2004); Morgan and Hunt (1994).

Secondly, trust is built via satisfaction, solving conflicts effectively, affective commitment, collaboration, willingness to invest, and expectation of continuity. Therefore, to be trusted from businesses, universities have to stress these variables in dealing with their stakeholders by focusing on graduating high caliber graduates, especially in the long run. Third, satisfaction is the result of effective collaboration between universities and businesses, conflicts' solving successfully and satisfactory, mutual affective commitment, willing to invest, and expectation of business continuity in the foreseen future. Fourth, universities' ways of solving functional conflict affected by the level of collaboration, expectation of continuity, willingness to invest, and commitment between universities and businesses. Fifth, affective commitment is affected by universities-industry (U-I) collaboration level, expectation on continuity, and willingness to invest. Sixth, expectation of continuity is affected by both level of collaborative interactions, and willingness to invest. Seventh, both industry's satisfaction and industry's commitment are different across type of business, ownership, experience, size, and frequency of collaboration (i.e. demographics). Finally, although the current study followed the footsteps of Marta et al. (2012) who in turn followed the footsteps of Siegel et al. (2003) it adds up the demographics effects to U-I relationships and it's a contribution from a middle east background university.

\section{References}

Abramo, G., D’Angelo, C. A., \& Di Costa, F. (2011). University-Industry Research Collaboration: A Model to Assess University Capability. Higher Education, 62(2), 163-181. http://dx.doi.org/10.1007/s10734-010-9372-0

Anderson, E. W., \& Sullivan, M. W. (1993). The Antecedents and Consequences of Customer Satisfaction for Firms. Marketing Science, 12(2), 125-143. http://dx.doi.org/10.1287/mksc.12.2.125

Anderson, J. C., \& Narus, J. A. (1990). A Model of Distributor Firm and Manufacturer Firm Working Partnerships. Journal of Marketing, 54(1), 42-58. http://dx.doi.org/10.2307/1252172

Arambewela, R., \& Hall, J. (2009). An Empirical Model of International Student Satisfaction. Asia Pacific Journal of Marketing and Logistics, 21(4), 555-569. http://dx.doi.org/10.1108/13555850910997599

Arif, S., Ilyas, M., \& Abdul, H. (2013). Student Satisfaction and Impact of Leadership in Private Universities. The TQM Journal, 25(4), 399-416. http://dx.doi.org/10.1108/17542731311314881

Ballart, X., \& Subirats, J. (1997). Science and Technology Policy for a Mid-size Industrial Country: The Case of Spain. Science and Public Policy, 197-205.

Bowden, J. (2011). Engaging the Student as a Customer: A Relationship Marketing Approach. Marketing Education Review, 21(3), 211-228. http://dx.doi.org/10.2753/MER1052-8008210302

Bryman, A., \& Cramer, D. (1999). Quantitative Data analysis with SPSS Release 8 for Windows: A Guide for Social Scientists. London: Routledge.

Chan, Y., Huff, S., \& Copeland, D. G. (1998). Assessing Realized Information Systems Strategy. Journal of Strategic Information Systems, 6, 273-298. http://dx.doi.org/10.1016/S0963-8687(97)00005-X

Crespo, M., \& Dridi, H. (2007). Intensification of University-Industry Relationships and its Impact on Academic Research. Higher Education, 54, 61-84. http://dx.doi.org/10.1007/s10734-006-9046-0

Croker, A., Joy, H., \& Fanziska, T. (2009). What Do We Mean by 'Collaboration' and When is a 'Team' Not a 'Team'?-A Qualitative Unbundling of Terms and Meanings. Qualitative Research Journal, 9(1), 28-42. http://dx.doi.org/10.3316/QRJ0901028 
Duncan, M., \& Jana, L. B. (2012). An Appealing Connection-The Role of Relationship Marketing in the Attraction and Retention of Students in an Australian Tertiary Context. Asian Social Science, 8(14), 65-80.

El-Ragal, A. (2001). Building DSS Using Knowledge Discovery in Database Techniques: Applied to Admissions and Registration Functions (Unpublished PhD Thesis). Business School, University of Plymouth, UK.

Foster, J. (2001). Data Analysis Using SPSS for Windows (2nd ed.). Sage Ltd., London.

Ghiselli, E., Campbell, J., \& Zedeck, S. (1981). Measurement Theory for the Behavioral Sciences. W. H. Freeman, San Francisco, USA.

Ghosh, A., Whipple, T., \& Bryanm, G. (2001). Student Trust and Its Antecedents in Higher Education. The Journal of Higher Education, 72(3), 322-340. http://dx.doi.org/10.2307/2649334

Gunasekara, A. (2006). Reafirming the Role of Universities in the Development of Regional Innovation Systems. Journal of Technology Transfer, 31, 101-113. http://dx.doi.org/10.1007/s10961-005-5016-4

Juran, J. M. (1988). Leadership for Quality: An Executive Handbook. New York, NY: The Free Press.

Keil, M., Mann, J., \& Rai, A. (2000). Why Software Projects Escalate: An Empirical Analysis and Test of Four Theoretical Models. MIS Quarterly, 24(4), 631-664. http://dx.doi.org/10.2307/3250950

Kline, P. (1997). An Easy Guide for Factor Analysis. London: Routledge.

Kohengkul, S., Wongwanich, S., \& Wiratchai, N. (2009). Influences of Strategies, Knowledge Sharing and Knowledge Transfer on the Success of University-School Collaboration in Research and Development. Research in Higher Education Journal, (5), 1-15.

Kotler, P., \& Clarke, R. (1987). Marketing for Healthcare Organizations. Prentice-Hall, Englewood Cliffs, NJ.

Kumar, N., Scheer, L. K., \& Steenkamp, J. B. (1995). The Effects of Perceived Interdependence on Dealer Attitudes. Journal of Marketing Research, 32(3), 348-356. http://dx.doi.org/10.2307/3151986

Lam, L. W., \& Yan, L. (2014). The Identity-Based Explanation of Affective Commitment. Journal of Managerial Psychology, 29(3), 321-340. http://dx.doi.org/10.1108/JMP-02-2012-0036

Lotayif, M. (2009). Empirical Assessment and Application of SERVQUAL Evidence from UAE Banks. Faculty of Commerce Journal, Cairo University, 13, 33-43.

Lotayif, M. (2014). University Student (U-S) Relationship Marketing: A Causality Study with Evidence from an Egyptian University. The Journal of American Academy of Business, Cambridge (JAABC), 19(2), 56-66.

Malhotra, N. K. (1993). Marketing Research an Applied Orientation. New Jersey, USA: Prentice-Hall, Inc.

Meyer, J. P., \& Herscovitch, L. (2001). Commitment in the Workplace: Toward a General Model. Human Resource Management Review, 11(3), 299-326. http://dx.doi.org/10.1016/S1053-4822(00)00053-X

Mohr, J. J., \& Nevin, J. R. (1990). Communication Strategies in Marketing Channels: A Theoretical Perspective. Journal of Marketing, 50(3), 36-51. http://dx.doi.org/10.2307/1251758

Mora, E. M., Montoro, A., \& Guerras, L. A. (2004). Determining Factors in the Success of R\&D Cooperative Agreements Between Firms and Research Organizations. Research Policy, 33(1), 17-40. http://dx.doi.org/10.1016/S0048-7333(03)00087-8

Morgan, R. M., \& Hunt, S. D. (1994). The Commitment-trust Theory of Relationship Marketing. Journal of Marketing, 58(3), 20-38. http://dx.doi.org/10.2307/1252308

Motohashi, K. (2005). University-Industry Collaborations in Japan: The Role of New Technology-based Firms in Transforming the National Innovation System. Research Policy, 34, 583-594. http://dx.doi.org/10.1016/j.respol.2005.03.001

Nunnally, J. C. (1978). Psychometric Theory (2nd ed.). New York: McGraw-Hill.

Oliver, R. L. (1980). A Cognitive Model of the Antecedents and Consequences of Satisfaction Decisions. Journal of Marketing Research, 17, 460-469. http://dx.doi.org/10.2307/3150499

Ortuzar, J. D., \& Willumsen, L. G. (1994). Modelling Transport. New York: John Wiley and Sons Ltd.

Palmatier, R. W., Dant, R. P., \& Grewal, D. (2007). A Comparative Longitudinal Analysis of Theoretical Perspectives of Interorganizational Relationship Performance. Journal of Marketing, 71(4), 172-194. http://dx.doi.org/10.1509/jmkg.71.4.172

Palmatier, R. W., Dant, R. P., Grewal, D., \& Evans, K. R. (2006). Factors Influencing the Effectiveness of 
Relationship Marketing: A Meta-Analysis. Journal of Marketing, 70(4), 136-153. http://dx.doi.org/10.1509/jmkg.70.4.136

Plewa, C., \& Quester, P. (2008). A Dyadic Study of 'Champions' in University-Industry Relationships. Asia Pacific Journal of Marketing and Logistics, 20(2), 211-226. http://dx.doi.org/10.1108/13555850810864560

Plewa, C., Quester, P., \& Baaken, T. (2005). Relationship Marketing and University-Industry Linkages: Aconceptual Framework. Marketing Theory, 5(4), 431-454. http://dx.doi.org/10.1177/1470593105058824

Ravichandran, T., \& Rai, A. (2000). Quality Management in Systems Development: An Organizational System Perspective. MIS Quarterly, 24(3), 381-415. http://dx.doi.org/10.2307/3250967

Rust, J., \& Golombok, S. (1999). Modern Psychometrics (2nd ed.). London: Routledge.

Saravanan, R., \& Rao, K. S. P. (2007). Measurement of Service Quality from the Customer's Perspective-An $\begin{array}{lllll}\text { Empirical Study. } & \text { Total } & \text { Quality } & \text { Management, } & 18(4),\end{array}$ http://dx.doi.org/10.1080/14783360701231872

Siegel, D., Waldman, D. A., Atwater, L. E., \& Link, A. N. (2003). Commercial Knowledge Transfers from Universities to Firms: Improving the Effectiveness of University-Industry Collaboration. The Journal of High Technology Management Research, 14(1), 111-133. http://dx.doi.org/10.1016/S1047-8310(03)00007-5

Stodnick, M., \& Pamela, R. (2008). Using SERVQUAL to Measure the Quality of the Classroom Experience. Decision Sciences Journal of Innovative Education, 6(1), 115-134. http://dx.doi.org/10.1111/j.1540-4609.2007.00162.x

Teo, T., \& King, W. (1996). Assessing The Impact of Integrating Business Planning and IS Planning. Information and Management, 30, 309-321. http://dx.doi.org/10.1016/S0378-7206(96)01076-2

Ulaga, W., \& Eggert, A. (2006). Relationship Value and Relationship Quality. Broadening the Nomological Networks of Business to Business Relationships. European Journal of Marketing, 40(3), 311-327.

Wonnacott, T. H., \& Wonnacott, R. J. (1990). Introductory Statistics for Business and Economics. John Wiley and Sons Inc.

\section{Copyrights}

Copyright for this article is retained by the author(s), with first publication rights granted to the journal.

This is an open-access article distributed under the terms and conditions of the Creative Commons Attribution license (http://creativecommons.org/licenses/by/3.0/). 